\title{
Effectiveness of Voluntary Measures to Reduce Agricultural Impact on Groundwater as a Source for Drinking Water: Lessons Learned from Cases in the Dutch Provinces Overijssel and Noord-Brabant
}

\author{
Cors van den Brink ${ }^{1,2, *}$, Marije Hoogendoorn ${ }^{3}$, Koos Verloop $^{4}$, Alma de Vries ${ }^{1}$ and Peter Leendertse ${ }^{3}$ \\ 1 Royal HaskoningDHV, P.O. Box 8064, 9702 KB Groningen, The Netherlands; alma.de.vries@rhdhv.com \\ 2 Faculty of Spatial Sciences, Groningen University, P.O. Box 800, 9700 AV Groningen, The Netherlands \\ 3 Center for Agriculture and Environment, P.O. Box 62, 4100 AB Culemborg, The Netherlands; \\ mhoogendoorn@clm.nl (M.H.); pele@clm.nl (P.L.) \\ 4 Faculty of Agrosystem Research, Wageningen University, P.O. Box 16, 6700 AA Wageningen, \\ The Netherlands; koos.verloop@wur.nl \\ * Correspondence: cors.van.den.brink@rhdhv.com; Tel.: +31-620139738
}

Citation: van den Brink, C.; Hoogendoorn, M.; Verloop, K.; de Vries, A.; Leendertse, P. Effectiveness of Voluntary Measures to Reduce Agricultural Impact on Groundwater as a Source for Drinking Water: Lessons Learned from Cases in the Dutch Provinces Overijssel and Noord-Brabant. Water 2021, 13, 3278. https://doi.org/10.3390/w13223278

Academic Editors: Frode Sundnes and Sindre Langaas

Received: 6 October 2021

Accepted: 16 November 2021

Published: 19 November 2021

Publisher's Note: MDPI stays neutral with regard to jurisdictional claims in published maps and institutional affiliations.

Copyright: (c) 2021 by the authors. Licensee MDPI, Basel, Switzerland. This article is an open access article distributed under the terms and conditions of the Creative Commons Attribution (CC BY) license (https:// creativecommons.org/licenses/by/ $4.0 /)$.

\begin{abstract}
Agricultural practices cause diffuse water pollution issues, which is a policy concern across the globe. This paper addresses the reduction in agricultural impact on groundwater as source for drinking water with a governance approach based on a mutual gains approach (MGA) using voluntary measures only. We performed case studies in Overijssel and in Noord-Brabant, both located in the Netherlands, to study the effectiveness of the governance approach on nutrients and pesticides, respectively. The effectiveness was studied by analyzing the engagement process qualitatively and by analyzing the impact of measures at farm scale as quantitative indicators. For nutrients, the effectiveness is expressed in the $\mathrm{N}$-surplus at farm scale and the realization of groundwater quality objectives in groundwater protection areas (GWPA). For pesticides, the effectiveness is expressed in environmental impact points (EIP) at farm scale and the level of groundwater protection areas (GWPA). The results indicate that the engagement process based on voluntariness creates a platform for meaningful engagement, adds to the economics of the farm and reduces the agricultural impact on groundwater quality. However, the nitrate objectives of the Water Framework Directive (WFD) are not met at the level of GWPAs in Overijssel. Due to the voluntariness of the approach, the participation rate relies on the farmers' expectation of the costs and benefits of the process, and diminishing economic returns prevent the further improvement of efficient nutrient use. Although an enforceable objective and strict deadline for pesticides is missing, the objective has been met at the level of GWPAs using voluntary measures only in Noord-Brabant. An important driver for this effectiveness is the fact that these results can be obtained without incurring economic losses, which may tie into the high participation rate of farmers.
\end{abstract}

Keywords: non-point source pollution; nutrient management; pesticide management; groundwater quality; water governance; voluntary measures

\section{Introduction}

\subsection{Agricultural Impact on Groundwater Quality}

Diffuse water pollution from agriculture and its governance is a policy concern across the globe. Groundwater is an important resource for drinking water and the functioning of ecosystems. Groundwater provides two-thirds of the drinking and industrial water required in the Netherlands. The two provinces included in this study, Overijssel and Noord-Brabant (referred to as Brabant hereafter), are entirely dependent on groundwater as a resource for drinking water. Groundwater bodies are dynamic systems with water coming into infiltration areas and leaving the system in seepage areas or by abstraction. 
Groundwater flows very slow, which causes residence times of groundwater in the subsoil, ranging anywhere between decades and thousands of years. Therefore, it may take that same amount of time before adverse effects of human activities on groundwater quality are noticeable. In line with that, remedial measures may take equally long to be effective. As a result of the very long recovery times and the sometimes large spatial scales of the impact of human activities, groundwater is considered to be extremely vulnerable to human influences [1]. Land use in the Netherlands is intensive. Furthermore, due to the high population density, different types of land use occur in relatively close proximity to each other. As a result, groundwater conflicts between the various land uses frequently occur. For example, the productivity of Dutch agriculture has strongly increased since World War II [2,3]. Simultaneously, the use of nutrients and pesticides increased. Especially in the vulnerable sandy areas in the eastern Pleistocene part of the Netherlands [4], emissions of nutrients and pesticides into the abstractions of groundwater for public water supply have caused serious concerns [5].

\subsection{Groundwater Governance as a Complex Environmental Problem}

The impact of agricultural activities on groundwater quality has been visible since the 1990s, and the stepwise reduction in nutrient and pesticide application has been implemented to reduce this impact [6,7]. The first stage of this reduction was initiated by the national authorities and was dominated by technical experts who evaluate quantitatively, within the context of an accepted scientific paradigm [8]. The extent of this reduction reflected the power balance behind governance at a national level [9].

Since 2000, the Water Framework Directive (WFD) has provided the overall framework and time-bound objectives for groundwater quality [10]. During this period, Dutch environmental policymaking has increasingly moved from national to regional and local authorities. This decentralization also shifted power to the local and regional level, where authorities moved to a new spatial management system that is based on water basins [11]. At the same time, environmental policy has become embedded in the social and economic processes of parties other than governmental organizations, such as businesses, non-governmental organizations and citizens [12]. In addition, there is a growing consensus within the policy community itself that expert-driven approaches do not suffice when dealing with problems related to environmental risks $[13,14]$. As a consequence, many regional processes in the Netherlands are now organized as bottom-up processes, in which the stakeholders negotiate with each other in a network structure, instead of top-down processes with the government as the dominant party [15-17]. In such bottom-up processes, it is important that the stakeholders are provided with the knowledge and information they need to actively take part in the process. Complex environmental problems are a particular challenge because they are 'quasi-scientific'. This means that more than scientific knowledge alone needs to be considered during problem-solving processes [18] Groundwater protection is an important example of a complex environmental problem where policies impact peoples' practice, work and economic situation, as is the case for farmers in agricultural areas. Current research indicates that a broader and more inclusive risk analysis approach is needed. A key part of this broader approach is the inclusion of members of affected communities in order to combine expert science with local knowledge, beliefs and values during problem-solving processes. This helps to avoid inefficient policies, protests and conflict [18-21].

The development of the Drinking Water Protection Files (DWPF) has helped combining risk analysis and expert science with local knowledge and societal values as an instrument in the governance of Drinking Water Protection Areas (DWPA) in the Netherlands [5]. The compilation of the DWPF is a process-oriented approach in which a risk analysis is carried out for each individual drinking water abstraction with local and regional stakeholders, in order to meet the WFD objectives [10]. As a result, various drinking water abstractions proved to be vulnerable to agricultural risks [22-26]. Ideally, by involving a broad set of stakeholders, the DWPF approach enlarges the knowledge base of the 
processes, increasing both the legitimacy of the outcomes and the experienced ownership influence over them [27].

\subsection{Groundwater Quality Governance by Voluntary Measures}

Although legal frameworks such as the monitoring and control and enforcement of regulations are seen as fundamental components of groundwater governance [28], DWPAs are conventionally managed through one or more of the following policy instruments in the Netherlands $[29,30]$. First, they may involve command and control regulation, such as nationally dictated limits for applied nitrogen per hectare. Second, they may concern voluntary adoption of the best management practices, resulting in improvements in environmental and farm management. Third, they may involve market-based incentives, such as fertilizer taxes, 'cap-and-trade' schemes for nutrients or permission for agro-chemical use in a given area. Finally, they may use payments for ecosystem service (PES) compensation for production and income foregone [31,32]. None of these policies are likely to be sufficient and cost effective if used in isolation, from a policy perspective [32] or from a groundwater quality perspective $[33,34]$. In addition, the current political and socio-economic context in the Netherlands is unfavorable towards additional tightening of regulations and restrictions to the agricultural sector. For example, the Dutch parliament decided that WFD implementation should not lead to additional costs for the agricultural sector [35]. This implies that the WFD objectives must be met using voluntary measures only.

Voluntary adoption of the best management practices encouraged by farm advisory systems can help detect opportunities to protect the environment, whilst also saving on farm production and labor costs [32]. Examples include soil testing, precise application of fertilizers and effective manure management. High rates of adoption may be difficult to achieve without a complementary 'stick' provided by (a threat of) regulation. In addition, if actual change is hampered by farm income or availability of capital for investment, a complementary 'carrot' provided through subsidies and other forms of financial support may be necessary [32].

The Dutch regional governments have initiated participatory projects to engage with agricultural stakeholders in achieving environmental goals. In this study we analyze engagement processes of two Dutch projects: Farmers for Drinking Water Overijssel in the province of Overijssel and Clean Water for Brabant in Brabant. These were set up in 2011 and 2001, respectively, to help reduce the input of agricultural pollutants in the groundwater system in order to protect drinking water abstractions (The cases presented in this paper are part of the EU FAIRWAY (Farm systems that produce good water quality for drinking water supplies) project (727984) as multi-actor platforms. The overall objective of the FAIRWAY project is to review current approaches and measures for the protection of drinking water resources against pollution caused by pesticides and nitrate from agriculture [36]). In these projects, farmers are supported by agricultural advisors through a "mutual gains approach"; the projects focus on a more efficient use of nutrients and a reduction in pesticide impact on groundwater. This, in turn, reduces leaching to the groundwater and results in economic benefits for the farmer. In the projects, knowledge and experience is additionally exchanged between farmers and professionals during group meetings with the aim of creating selfimproving agricultural management regarding the use of nutrients and pesticides. The main question addressed in this paper is how effective of voluntary measures are in reducing agricultural impact on groundwater as source for drinking water. We reflect on this question qualitatively by analyzing the engagement processes, quantitatively by looking into measures at a farm level and through the realization of groundwater quality objectives in GWPAs. 


\section{Case Studies and Methods}

2.1. Description of the Cases

2.1.1. Overijssel

From 2011 onwards a consortium has carried out the project. Royal HaskoningDHV (RHDHV) is responsible for the overall management, groundwater quality and WFD issues. Wageningen University and Research (WUR) is responsible for agricultural advice, prototyping farm management. Countus is responsible for agricultural accountancy. Stimuland is responsible for communication. The province is the regional authority regarding the protection of groundwater as source for drinking water. The drinking water company is responsible for the production of clean and reliable drinking water.

The project in Overijssel started in the recharge areas of 5 vulnerable drinking water abstractions in the province (Archemerberg, Herikerberg, Wierden, Hoge Hexel and Espelose Broek) and consists of 7 areas today. They are Archemerberg, Holten, Herikerberg, Wierden, Hoge Hexel, Manderveen and Espelose Broek. Farmers who owned parcels in recharge areas of the initial 5 vulnerable abstractions were invited to participate in the project. The platform in which farmers, agricultural advisors and accountants, communication and groundwater quality experts, authorities and water companies discuss and work together is referred to as a multi-actor platform (MAP)

Other farmers (neighbors, et cetera) as well as agricultural contractors, municipalities and the regional press were invited to facilitate the implementation of measures which are believed to be relevant for both the farmer and the groundwater quality, but less relevant for the groundwater quality in the vulnerable GWPA. Since 2017, the pilot Farmers for Drinking Water has been part of a larger regional project (Fertile Cycle OverijsselVruchtbare Kringloop Overijssel-VKO). In this project, additional financing stakeholders are involved: water authorities (water authority Drents Overijsselse Delta, water authority Vechtstromen and water authority Rijn and IJssel), farmers lobby organization LTO, cattle feed companies (Agrifirm and ForFarmers) and financial institutions such as the most common agricultural bank (Rabobank). These regional stakeholders of VKO are not particularly active in the pilot Overijssel. They can, however assist in implementing the measures, knowledge and experiences from the pilot Overijssel in the bigger regional project because all relevant stakeholders and the project structure are available. Currently, 26 dairy farmers participate in the project.

The soil is mostly sandy with groundwater tables typically at $2-4 \mathrm{~m}$-sl, indicating that changes in nitrate concentration of water leaching from the root zone might be detectable in 2-4 years in the shallow phreatic groundwater, considering an infiltration rate of approximately $1 \mathrm{~m}$ per year [4]. Land use consists of agricultural land use (mainly dairy farming with $80 \%$ grass and $20 \%$ maize), nature and some urban areas. The measures to be implemented are focused on reduction in the nitrate and pesticide leaching towards groundwater in the recharge areas of vulnerable abstraction sites in Overijssel, while improving the operational result of the farm through better nutrient management and more specific use of pesticides.

Typical nitrate concentrations in the upper phreatic groundwater at the start of the pilot were, on average, $92-161 \mathrm{mgNO}_{3} / \mathrm{L}$ in maize and $64-86 \mathrm{mgNO}_{3} / \mathrm{L}$ in grassland. All groundwater abstractions show hardness of the water has increased due to manure application in the past. In individual abstraction wells, the nitrate standard is exceeded in Herikerberg/Goor, Wierden and Archemerberg [5]. Nickel concentration in Hoge Hexel exceeds the standard of $15 \mu \mathrm{g} / \mathrm{L}$ due to pyrite oxidation from nitrate-containing groundwater [5].

In addition to the province and water company having an interest in groundwater meeting the WFD objectives, MAP participants have mentioned various reasons to join the MAP. Farmers have mentioned that they have been invited to participate or that they prefer to look for common ways to solve the issue rather than being confronted with new and additional rules and regulations. Groundwater quality experts mention the input of knowledge and the fact that Farmers for Drinking Water is a measure/project following the 
assessment of the risks of the individual drinking water abstraction sites in Overijssel. The agricultural advisors and accountants mention their position as a connecting link between farmers and policy.

\subsubsection{Brabant}

Clean Water for Brabant has been initiated and funded by the province of Brabant, the water company Brabant Water and the water authorities (water authority Brabantse Delta, water authority Aa en Maas, water authority De Dommel and water authority Rivierenland) since 2001. The province is the regional authority regarding the protection of groundwater as source for drinking water. The water authorities are the regional authorities for the surface water quality. The drinking water company is responsible for the production of clean and reliable drinking water. The agricultural organization (ZLTO) contributes to the project in-kind by facilitating communication between their members and offering links to agricultural education.

From 2001 onwards a consortium carried out the project. Within this consortium, Research and Advice (CLM) is responsible for the overall management and communication, Delphy gives agricultural advice and EcoConsult provides advice to greenkeepers and gardeners. This consortium selected and invited farmers and contractors if they had parcels of land in recharge areas of 1 of 11 vulnerable groundwater abstractions. From 2012 onwards, growers (of potatoes, strawberries, leek, green beans, ornamentals) and contractors from the whole of Brabant were invited to participate in the project. This was driven by the desire of the water boards to broaden the focus towards both ground and surface water and by the desire of ZLTO to make 'mutual gain' measures more widely available to growers.

Clean Water for Brabant currently consists of 11 GWPAs and 750 growers on more than 60,000 ha in the south of the Netherlands, in the province of Brabant. This province has an area of $4919 \mathrm{~km}^{2}$ and it is populated by 2.48 million inhabitants. The northern border follows the Meuse (Maas) river westward to its mouth in the Hollands Diep strait, part of the Rhine-Meuse-Scheldt delta. Drinking water is abstracted from groundwater at 39 locations in the province, with an annual production of 180 million $\mathrm{m}^{3}$. In addition, Brabant is part of the catchment area of the river Meuse. The surface water of the Meuse is a source for drinking water for 3 million people in the western part of the Netherlands. The abstraction sites for drinking water in Brabant vary in depth and vulnerability. The shallow and most vulnerable sites are surrounded by GWPAs. The case study Brabant focuses on is pesticide reduction in current and future drinking water resources, considering the national and European regulations and laws. The monitoring program carried out by Brabant Water and the provincial authorities shows that the use of pesticides is a threat to the groundwater in 11 of the 39 abstraction areas. The strategy to produce high-quality tap water revolves around prevention but, if necessary, also includes water purification. In Brabant, pesticide concentrations in ground and surface water are measured every four years at a large scale [34], confirming the concern that pesticides may leach out of the root zone and eventually reach phreatic and deeper groundwater.

A MAP was put in place to facilitate communication between farmers, the province and water company. Among other things, this contributed to shared goals and insight in dilemmas and provided a platform to exchange ideas and concerns.

\subsection{Data Collection}

The data collection has been organized along two tracks. These tracks are (i) the engagement process in which qualitative information is collected about the functioning of the MAP and (ii) quantitative data on agricultural management from the Annual Nutrient Cycle Assessment (ANCA) for nitrogen $[3,37,38]$ and the Environmental Yardstick for pesticides $[26,39,40]$. In addition, the nitrate concentration is measured in the upper phreatic groundwater in the GWPAs in Overijssel to provide the farmers with feedback concerning the impact of agricultural management and measures to change this impact [41]. 


\subsubsection{Engagement Process}

Meaningful engagement and a well-functioning MAP is important when the governance approach consists of voluntary measures only. A key element for the engagement process is that agricultural advisors approach the farmers, their farms and their agricultural management with a genuine interest, looking for a mutual gain rather than individual benefit [42].

Since the start of the projects in 2011 (in Overijssel) and 2001 (in Brabant), the authors have participated in farm visits and discussed the primary results of previous farm visits prior to the growing season to discuss management strategies and plan actions. Furthermore, a visit was organized at the end of the growing season to evaluate the experiences and results. Moreover, two meetings were annually organized for clusters of 6-10 participants to discuss technical issues. In the Overijssel case, these issues concerned farm nutrient management, grazing management, and optimizing the timing of fertilization and the distribution of parcels. In the Brabant case, these issues concerned crop protection management, the use of alternative pesticides and optimizing the application of pesticides and the precise use of pesticides. In addition, alternatives to pesticides, such as mechanical weeding, and management of point-source emission was part of the planned actions. An overview of these activities is listed in Table 1. These activities have been documented in activity logs as part of the FAIRWAY project.

Table 1. Overview of yearly engagement activities and meetings in the case studies of Overijssel and Brabant. The participation rate is in brackets.

\begin{tabular}{|c|c|c|c|c|}
\hline & $\begin{array}{l}\text { Farmers for Drinking } \\
\text { Water Overijssel } \\
\text { Since } 2011\end{array}$ & Stakeholders & $\begin{array}{l}\text { Clean Water for } \\
\text { Brabant Since } 2001\end{array}$ & Stakeholders \\
\hline $\begin{array}{l}\text { Individual farm } \\
\text { management advice }\end{array}$ & 2 & $\begin{array}{l}\text { Farmer and } \\
\text { agricultural advisor }\end{array}$ & 1 & $\begin{array}{l}\text { Farmer and } \\
\text { agricultural advisor }\end{array}$ \\
\hline Small group meeting & $\begin{array}{l}2-4 \text { (6 out of } \\
10 \text { farmers })\end{array}$ & $\begin{array}{c}\text { Farmers and } \\
\text { agricultural } \\
\text { advisor/expert }\end{array}$ & 1 (10-15 farmers) & $\begin{array}{l}\text { Province, water } \\
\text { company, water } \\
\text { authority, farmers }\end{array}$ \\
\hline Field demonstration & $2-4$ & $\begin{array}{l}\text { Province, water } \\
\text { company, agricultural } \\
\text { lobby organization, } \\
\text { agricultural advisors, } \\
\text { groundwater quality } \\
\text { experts, farmers and } \\
\text { regional stakeholders } \\
\text { outside the GWPAs }\end{array}$ & 3 & $\begin{array}{c}\text { Farmers, experts, } \\
\text { province, water } \\
\text { company, water boards }\end{array}$ \\
\hline $\begin{array}{l}\text { Crop groups (e.g., } \\
\text { arable, tree nursery, } \\
\text { asparagus) }\end{array}$ & & & $\begin{array}{l}1-2 \text { indoor; } \\
1-2 \text { in the field ( } 50 \% \text { of } \\
\text { the farmers, group size } \\
10-15 \text { of groups } \\
\text { ranging from } 15 \text { to } \\
150 \text { farmers) }\end{array}$ & $\begin{array}{l}\text { Farmers and } \\
\text { agricultural } \\
\text { advisor/expert }\end{array}$ \\
\hline Annual meeting & 1 (20 out of 26$)$ & $\begin{array}{l}\text { Province, water } \\
\text { company, agricultural } \\
\text { lobby organization, } \\
\text { agricultural advisors, } \\
\text { groundwater quality } \\
\text { experts, farmers }\end{array}$ & $1(250-375$ out of 750$)$ & $\begin{array}{c}\text { Province, water } \\
\text { company, water } \\
\text { authority, agricultural } \\
\text { lobby organization, } \\
\text { agricultural advisors, } \\
\text { farmers }\end{array}$ \\
\hline
\end{tabular}

In addition, a survey was carried out in 2019 with a focus on multi-actor engagement and dimensions that are considered relevant for assessing strengths, weaknesses and opportunities for change with regards to engagement platforms. This survey was also part of the FAIRWAY project [43]. Attempts were made to enroll all relevant actors in the two 
cases to the surveys. For Overijssel, this survey was answered by 10 respondents, among them farmers [4], agricultural advisers [5] and the agricultural lobby organization [1] The province of Overijssel and the water company Vitens, the main stakeholders, did not respond. For Brabant, this survey was answered by 10 respondents, among them the main stakeholders: farmers, the water company, the water board, agricultural advisors and the province. In addition, feedback from the farmers about the project and vice versa was collected during annual evaluation meetings and through questionnaires.

\subsubsection{Farm Scale Measures and Targets}

Agricultural management is supported quantitatively by a farm management plan based on the ANCA and Environmental Yardstick which the farmer and advisor agree to. This plan contains an overview of possible measures in combination with an indication of whether the measure is relevant, already implemented, to be implemented next growing season or a possible option in a future year. The key element of this farm management plan was the quantitative analysis of the N-surplus by the ANCA (Overijssel) and the EIP (Brabant) by the Environmental Yardstick. The N-surplus and EIP serve as quantitative indicators for agricultural management.

An important aspect of agricultural management is setting targets directly related to the agricultural management of the farmer. For nutrients, the targets are set at $80-100 \mathrm{kgN} / \mathrm{ha} /$ year. For pesticides, the targets were set at 500 environmental impact points (EIP) for groundwater per year. The nutrient targets were derived directly from the ANCA, and the pesticide targets were derived directly from the Environmental Yardstick. The relation between the targets for farm management and the nitrate concentrations in shallow phreatic groundwater were based on empirical relations [44].

\subsubsection{Groundwater Quality}

A stratified monitoring design was used to enable the extrapolation of the measured nitrate concentrations from the entire agricultural area with respect to the occurring strata. The strata consist of soil type (\#5), groundwater table (\#3) and land use (\#2), totaling 30 unique combinations [45]. The sampling procedure follows the procedure used for the Minerals Policy Monitoring Programme (LMM or 'Landelijk Meetnet effecten Mestbeleid') to monitor the impact of manure policy $[46,47]$. The density of sample locations was approx. 170 sample points per 201 hectares of agricultural area. The upper meter of the groundwater, occurring within three meters of the surface, was sampled. Water, sampled with a well screen and using a suction pump, was directly filtered using a $0.45 \mathrm{pm}$ filter, then acidified and stored at $4{ }^{\circ} \mathrm{C}$ prior to chemical analysis $[46,48]$. If the phreatic groundwater level was deeper than 3 m-ss, a soil moisture sample was taken from a depth of 1.5-3.0 m-ss, in line with parameters proposed by De Goffau [48] and Fraters [49].

Groundwater quality for pesticides in Brabant is monitored by the National Groundwater Quality Monitoring Program (LMG) according to the method of van Duijvenboden [50]. Groundwater quality was measured in 350 sample points, 56 of which were in Brabant, taken at depths of 10, 15 and $25 \mathrm{~m}$ minus the soil surface. Additionally, Brabant had 66 sampling points for the Provincial Groundwater Quality Monitoring Program (PMG, or 'Provinciale Meetprogramma's Grondwaterkwaliteit'), which follows the same methodology as the LMG [34]. The yearly impact of pesticide use on groundwater in Brabant is also monitored using the Environmental Yardstick. All farmers register their pesticide use, and the environmental impact on groundwater is calculated using the EIP of each pesticide as function of the organic matter content of the soil. The pesticide impact is calculated per crop and for the total project [26].

\subsection{Economic Analysis}

An analysis of the economic impact of the measures was caried out to illustrate the benefit farmers may have from implementing measures as part of the MGA. The analysis was carried out quantitatively by an economic valuation of the ANCA indica- 
tors for the Overijssel case. The economic valuation used in the pilot project is widely accepted in Dutch dairy farming. Here, the determination of the value of fodder is based on the fodder valuation method of Wageningen Livestock Research. Every four weeks, Wageningen Livestock Research calculates the actual prices of fodder in dairy farming (https:/ / www.wur.nl/nl/Expertises-Dienstverlening/Onderzoeksinstituten/li vestock-research/Producten/Voederwaardeprijzen-Rundvee.htm, accessed on 27 December 2020). For the Brabant case, the economic impact of measures was carried out by qualitatively evaluating costs savings and subsidies.

\subsection{Case Studies}

The cases in Overijssel and Brabant are independent. Both cases are a response to a socio-economic issue regarding agricultural impact on groundwater as a source for drinking water, and they were not designed to be a comparative study. However, in the Overijssel case, a kind of benchmark was provided by using comparative agricultural data from existing databases. In the Brabant case, this benchmark was not at hand because databases with actual pesticide use were not available or accessible. It is argued in literature that one cannot generalize from a case study, but according to Flyvbjerg [51], this statement is not true; case studies can serve as an example and can be valuable for scientific development. A case may be so important or interesting that it deserves study in its own right [52]. Thus, the intention of this research is not to draw general conclusions based on a case study, but rather to understand the case and its engagement process in its complexity and context. The insights provided contribute to effective cooperation between stakeholders and the successful implementation of strategies from the farm to the regional level that mitigate nitrate and pesticide pollution of vulnerable drinking water resources

\section{Results}

\subsection{Overijssel Case}

\subsubsection{Engagement Process}

At the start of Farmers for Drinking Water there was already a high level of awareness of the need to reduce the nitrate concentrations in the groundwater of the recharge areas concerned. The need to meet the nitrate objectives was clear for the participating farmers from the start, and some of them explicitly mentioned the focus of the project on economic aspects as important reason for participating. Farmer awareness and the information collected in Farmers for Drinking Water, such as the nitrate concentrations of the shallow phreatic groundwater and $\mathrm{N}$-surpluses of participating farms, have increased the understanding that farming in general contributes to groundwater pollution but also increased insight into their own role. Farmers are aware of the changes that agricultural farm management can make to reduce groundwater pollution. Often, the measures are not completely new to them: "I (the farmer) read and hear about measures implemented by colleagues but only after discussing these measures in the context of my farm with my advisor I feel confident enough to implement these measures myself". As result of the discussions with the farmers about the increase in their awareness, the scope of their management broadened: "I (the farmer) was used to focus on feeding cows, but now I'm also focused on feeding the soil with a focus on the groundwater quality".

Communication in regional and national press regarding the concern about groundwater quality as resource for drinking water is a sensible topic for the farmers, especially with press releases from the water company: "We (the farmers) trust the representative of the water company in Farmers for Drinking Water and know that that representatives support our effort, but press releases from the water company about their concern regarding the groundwater quality without mentioning Farmers for Drinking water feel as a stab in the back". During annual evaluation meetings, farmers are very positive about their experiences of Farmers for Drinking Water and indicate that advisors provide them with relevant and trusted advice. A vast majority of over $80 \%$ of the farmers indicate that working with their advisor increased the priority they give to nutrient management 
and-indirectly—groundwater pollution. Holding-specific, one-to-one advice based on genuine interest in the farmer and his farm management is most effective for building trust and confidence: "Together with the advisor, I (the farmer) selected a measure (i.e., application of manure to the maize in a row) which required a heavy vehicle. When it was time to apply the manure and sow the maize the soil was too wet. The advisor came to see and decided to cancel the measure". In addition, group interaction with other farmers at group events (peer group interaction) is important for developing farmers' confidence and skills, exchanging knowledge and experiences and establishing Farmers for Drinking Water as a good farming 'norm'. This way of trust building is also recognized by the farmers, as one of said: "In the MAP, you are talking with farmers rather than talking farmers". Furthermore, these peer group interactions have been used to invite well-selected experts to discuss a topic relevant for the group or suggested by the group.

The rule-of-thumb calculation of the economics of implemented measures strongly contributed to this attitude. although farmers also mention that "they haven't seen one single euro in the hand yet" referring to the fact that the province and water company do not pay for their effort, and the result of the measures becomes part of the nutrient efficiency at the farm level and is not settled financially measure by measure. At the same time, farmers also mention the future of the farm as reason to participate and improve their management to further reduce the impact on the groundwater: "in this catchment agriculture and drinking water are the main land use functions. When co-existence is not possible, I'm afraid that agriculture will have to move".

In annual meetings, we also asked the farmers how they would evaluate the project. Overall, farmers are very positive about their experiences of Farmers for Drinking Water, with the vast majority of over $80 \%$ agreeing (i) the project encouraged them to reduce water pollution, (ii) the advice received was relevant to their farm, (iii) they received enough information to enable them to introduce new ideas or changes on their farm and iv) they are satisfied with the help received. In addition, some of the front runners mentioned that the tool box of the advisors was getting empty over a period of 3-5 years, which was a reason for them to ask for subsidies or payment schemes to implement additional effective measures without any economic gain for the farmer or for extending the legal space for agricultural experiments.

Following a national agreement on an approach to reduce nitrate leaching in specific vulnerable GWPAs, also including the GWPAs of Farmers for Drinking Water Overijssel [53], the dynamics of the engagement process changed. Although the objectives and approach of the project did not change due to this agreement, the agreement did introduce a deadline for meeting the nitrate objective: the nitrate objective has to be met at the scale of the GWPA by 2025 at the latest (i.e., at the end of the 7th Nitrate Action Program). This deadline puts pressure on the engagement process. The concern of individual farmers of the Farmers for Drinking Water project about 'what will be next if we are not able to meet the groundwater quality standards' increased as result of this agreement, and they were openly questioning their participation more often than before.

\subsubsection{Farm Scale Measures}

Farm management changed significantly over time after the implementation of measures to reduce the $\mathrm{N}$-surplus and nitrate leaching. The implementation process evidently covered a wide range of farm management. Measures relating to both cattle and feed on the one hand and soil and crop management on the other have the highest uptake rates. Those methods that relate to farm infrastructure, such as enlarging manure storage capacity and land use change, generally have the lowest. The mean implementation fraction increased from 0.4 to 0.6 during the total runtime of the project. The reduction in the crude protein content in the ration as compared to the energy content in ration was implemented the most frequently, followed by restricted grazing intensity and rotational grazing strategy. As a soil and crop management measure, the early harvest of maize directly followed by sowing catch crop and catch crops with high $\mathrm{N}$-uptake capacity had a high implementation 
fraction, whereas the supply of manure in the rows where maize seeds are placed was only implemented on some farms. Most of the implementation of advice occurs within one year, but in some cases it can take an extended period of time. As a result of the one-on-one advice and shared interpretation of the ANCA, farmers gained a better understanding of how specific measures reduce water pollution, and they were much more likely to implement that measure [54].

Because the implementation of the measures is voluntary, this implementation depends on specific conditions of the farm (soil and groundwater situation, farm infrastructure, spreading of parcels, preferences of the farmer, et cetera). When measures were evaluated as 'probably not suitable' prior to implementation, this was associated with one or more of the following factors in most cases. First, there is the complexity of the measure. Second, there may be a misfit between the measure and the conditions on the farm, for instance, big machinery that must be operated on parcels that are too small. The final factor relates to uncertainties concerning the effectiveness of the measure [54].

\subsubsection{N-Surplus}

The N-surpluses were reduced in a period of 3-5 years (Figure 1 ). The average Nsurplus of the participating farms shows a significant decline from $154 \mathrm{~kg} \mathrm{~N}$ per ha per year ( $\mathrm{kg} \mathrm{N}$ per hectare per year (2020). This decrease of almost $12 \mathrm{~kg} \mathrm{~N}$ per year until 2017 and-except for 2018 - the constant level after, is a significant decrease considering that there were no additional general measures or policies implemented during this period. The fluctuations between years illustrate the dependence of the $\mathrm{N}$-surplus on climatic conditions, especially drought, which strongly impacts plant growth and the uptake of nutrients. This is most explicitly shown by the drought of 2018. As result of this drought, which was severe in the high sandy areas in the Netherlands and even more severe in the recharge areas in these high sandy areas, plant growth was retarded, resulting in an increased $\mathrm{N}$-surplus.

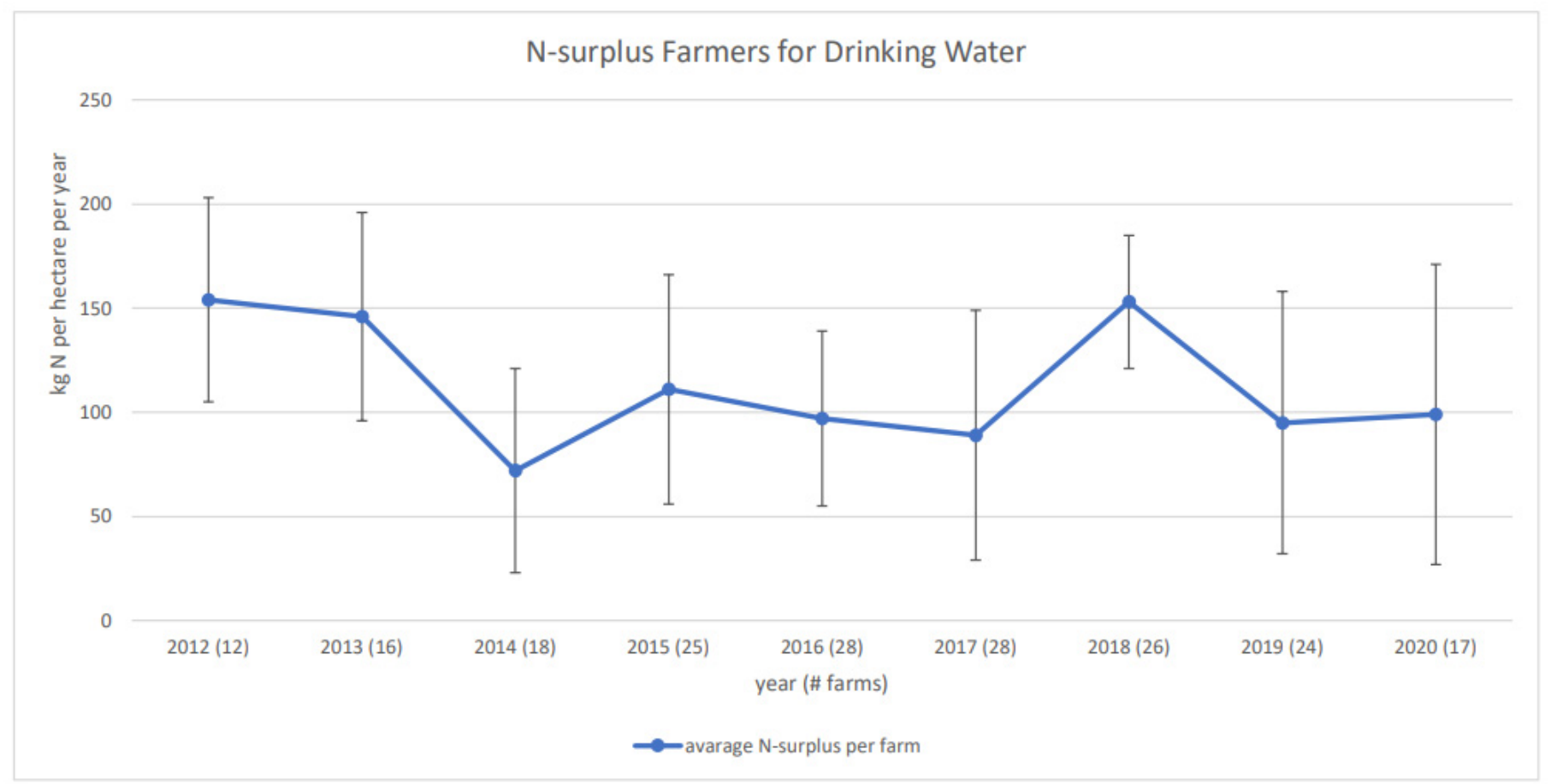

Figure 1. Dynamics of the N-surplus on the whole farm soil balance, average for all pilot farms per year.

The impact of implementing measures on reducing the $\mathrm{N}$-surpluses is high during the first 3-5 years. After that period, the N-surpluses stabilize, indicating that the measures which are effective in reducing the $\mathrm{N}$-surplus and have a business economic-gain (BE-gain) 
are implemented. An additional improvement is possible in the craftsmanship of executing the measures, but the implementation of new measures is hampered by a lack of BE-gain; additional measures cannot be motivated from economic perspective.

However, although the structure of improving agricultural management is evident in a theoretical sense (analysis of the ANCA to identify the most significant N-losses; selection of measures; analysis of ANCA to evaluate measures-and identify the newest most significant N-losses) farmers did not become autonomous in continuous improvement of farm management during the scope of the project. This is in part due to the fact that analysis of the ANCA requires more expert knowledge than most farmers have. A more economic reason might be that nutrients are cheap, indicating that nutrient efficiency is important from the groundwater quality perspective but not a necessity from BE perspective. Cost savings associated with lower fertilizer inputs are not considered by the farmers to prevent the risk of yield reduction, so continuous attention and challenging points of view from an advisor are required to maintain nutrient awareness.

\subsubsection{Economic Impact of Measures}

In the first years of the project, the implementation of measures had an economic gain of tens to hundreds of euros per hectare [54]. Self-improving agricultural management economically supported by more efficient use of nutrients seems feasible; farmers see the (economic) impact of measures improving nutrient efficiency and are increasingly eager to implement and carry out various measures. For newly introduced and implemented measures, the business economic gain could be calculated per individual measure per farm. The average BE-gain per farm is EUR 4200, for soil and crop management measures (with a range of approx. EUR 2100-6800) and EUR 2600, for cattle and feed management measures (with a range of approx. EUR 0-9600). This BE-gain, alongside lecturing and discussing this valuation method during (peer) group sessions, strongly increased commitment to improve cattle and nutrient management.

After implementing the measures in farm management and improving this management in one or several years after discussing this with the advisor, it was more difficult to relate the BE-gain to a specific measure. Therefore, the calculation of the BE-gain changed to the economics of 'nutrient efficiency at farm scale' [54]. With parameters from the ANCA, nutrient efficiency is expressed as the fodder production with own production means: the more efficient the nutrient management, the more fodder is produced with own production means (Table 2).

Table 2. Fodder profitability of dairy farmers from Farmers for Drinking Water compared to benchmark farmers.

\begin{tabular}{ccc}
\hline & Farm Efficiency in Fodder Production & \\
\hline & $\begin{array}{c}\text { Farmers for Drinking Water } \\
\mathbf{2 0 1 6 / 2 0 1 8 ~ ( \# 2 6 )}\end{array}$ & $\begin{array}{c}\text { Reference Dairy Farms } \\
\mathbf{2 0 1 6 / 2 0 1 8} \text { (\#500) }\end{array}$ \\
\hline $\begin{array}{c}(€ \text { per hectare) } \\
\text { Reference fodder production } \\
(€ \text { per hectare) }\end{array}$ & 3.835 & 4.132 \\
\hline Deviation $(€ /$ hectare $)$ & 3.878 & 4.132 \\
\hline
\end{tabular}

Table 2 shows that the nutrient efficiency over the period 2016-2018 is slightly less than 500 reference dairy farms in the region, while the N-surpluses of the participating farmers are significantly reduced. The main reason for this discrepancy is the drought of 2018. As previously mentioned, this drought retarded plant growth in that year.

The calculation of the BE-gain also revealed diminishing economic returns of the efforts of the farmers to further reduce agricultural impact; agricultural management has improved in such a way that additional measures cannot be motivated from an economic perspective alone. However, some improvement is possible in the craftsmanship with 
which the measures are executed. Voluntariness hampers the implementation of measures needed to further reduce the impact of agricultural activities which cannot be economically motivated. In discussions, farmers indicate that the measures implemented-given the sense of urgency they feel related to the 'license to produce' - may not be enough for optimal groundwater-friendly agricultural management. To move towards even more groundwater-friendly management, they expect the government to either provide payment schemes or legal space for more experimental measures benefitting both farmer and groundwater. An example of this would be to add more compost to the soil.

\subsubsection{Groundwater Quality}

The nitrate concentrations decreased in maize land but remained more or less constant in grass land areas [54]. The average nitrate concentration in agricultural areas, however, remained more or less constant within the agricultural area or showed only a small decrease. During the first 3-5 years, farmers and advisors were convinced the measures implemented would make a difference in the quality of the upper phreatic groundwater in their recharge area, because the ANCA showed decreasing N-surpluses in the first 3-5 years (Figure 1), and the travel time from soil surface towards the upper phreatic groundwater is approximately 3 years. During and after this period, however, no trend or decrease could be detected in the nitrate concentrations in the groundwater [54], which gave rise to concern. Although farmers consider the project to be successful in reducing the $\mathrm{N}$-surpluses, they are also concerned about future developments and the tenability of voluntariness. Especially when measures show a diminishing economic return on their efforts. In other words, agricultural management has improved in such a way that additional measures cannot be motivated from an economic perspective alone.

\subsection{Brabant Case}

\subsubsection{Engagement Process}

From the year 2000 onwards the drinking water company in Brabant became increasingly concerned about the pesticides found in the groundwater used for drinking water. The national regulation (based on the EU regulations) to protect the groundwater did not prevent the leaching of pesticides. Subsequently, in 2001 the drinking water company started a project-together with the province of Brabant- to stimulate the users of pesticides to reduce use and emission of pesticides in two of the most vulnerable GWPAs.

Accustomed to cooperating with other stakeholders, they adapted to the new challenge. Some of them had already switched to organic farming in the years before. In the other areas, Budel, farmers were initially suspicious, especially since the regional government warned the farmers that a ban on certain crops with high pesticide use might be implemented.

In the GWPAs, farmers receive free one-to-one advice from an independent farm advisor. The advisor helps them to implement sustainable crop protection, to understand the impact of their current use and the possibilities to reduce their emissions. Additionally, farmers have access to group meetings, field visits and demonstrations of new techniques with their advisor. Farmers consider this very useful. As one farmer explained: "It always teaches you something new. In the past we would see each other at auctions, but that doesn't happen anymore. The number of study groups has also decreased". For farmers outside GWPAs in Brabant, no one-to-one advice is available, but all participating farmers do have access to all group meetings.

The farmers set their suspicions aside after reassurance from the regional government that a ban would be reconsidered if they joined the Clean Water project. In the period between 2001 and 2009, the number of vulnerable GWPAs joining the project increased from 2 to 11. All landowners in the GWPAs were contacted with a request to join the project. This resulted in more than $85 \%$ of the area covered. A potato farmer explains why he joined: "Of course we have a wish to produce sustainably; my 400-year-old farm should 
still be in action 400 years from now. I'm also very interested in technical solutions, like my self-built biofilter".

There are annual meetings between the MAP members in varying compositions. The water authorities join group meetings to discuss measurements from the previous year. The water authorities will join meetings when there are new groundwater studies available to discuss successes and future challenges. Guiljo van Nuland from Brabant Water indicated in one of these meetings that "We still find pesticides in the water. Often a heritage of the past, but also pesticides which are still used. We are optimistic about what we can achieve by working together in this project (Clean Water for Brabant)". The meetings allow farmers to ask questions and discuss any constraints, such as the lack of alternatives to specific pesticides. The government agencies can then help solve the constraints, for example, by funding research and field experiments of alternative measures.

To stimulate the movement towards reducing emissions, the Clean Water project has an innovation budget of EUR 25,000 per year. Farmers with innovative ideas to reduce pesticide emissions in water can apply for the budget to co-finance investments. This can be an existing technical solution, such as a new low-drift sprayer or mechanical weeder, a self-developed solution, such as a weed burner. Alternatively, it can be a research budget to set up a trial plot with an advisor. The results or techniques are shared with the other project participants through a newsletter, mailings and group demonstrations. This way, the innovations are presented to farmers in Brabant.

\subsubsection{Farm Scale Measures}

The farm scale measures for the Clean Water approach can be categorized into four groups: (i) choice of pesticides, (ii) reduction in emissions, (iii) non-chemical alternatives and (iv) decision support tool. The choice of pesticides is facilitated by the Environmental Yardstick. This instrument is used to create environmental impact sheets, which summarize crop-specific information on the pesticides admitted, recommended doses and corresponding environmental impact. A green-yellow-red color system is used as a visual aid to distinguish pesticides with high and low environmental impact. The sheets are distributed and discussed with the farmers during group meetings before the growing season. The reduction in emissions is realized by the reduction in spray drift. There are several techniques available to reduce these routes, such as nozzle choice, low-drift sprayers and lower boom height. To avoid pesticide use altogether, several mechanical alternatives are available. Some techniques are readily available, such as mechanical hoeing, but a group of growers are also developing new techniques for their own specific needs. Autonomous systems are currently being investigated, as most mechanical weeding systems are time consuming. Finally, a decision support tool is used to choose the best moment of application and/or the weather conditions for optimal performance. One crop group has their own weather station to better predict their local conditions and pesticide needs.

The most important measures were bundled in the leaflet "Win-win measurements for clean water" [55]. The leaflet, which was distributed to farmers and is available online, gives an indication of the pros and cons, as well as costs and benefits, of the measures. New measures are constantly being researched and developed, either by farmers or the advisors. When a new constraint arises or a technique is deemed interesting, a farmer or a group of farmers will work on solutions. This often happens with aid through the innovation budget or directly with a government agency. It is then used for demonstration purposes. A good example of this is a group of nurserymen who were interested in mechanical weeding systems. As there were none available at the time, they started developing their own systems. Their solutions are demonstrated at meetings regularly.

An important feature in the Clean Water project is the collection of pesticide use data from all farmers within the protection areas and 30\% of farmers from the rest of Brabant. These data allow farmers to receive specific feedback about their progress compared to their peers. The information is discussed in one-on-one advice sessions, where the advisor helps find alternatives to the higher scoring pesticides. Additionally, group data is discussed in 
group meetings. Farmers receive their personal score and will have a group discussion on constraints and solutions. The independent advisor present can ask specific farmers why they chose alternative measures and how they worked. This direct feedback from peers is very useful in opening farmers up to new ideas.

\subsubsection{Environmental Impact Points}

The environmental impact points for groundwater in the GWPAs decreased from an average of $1601 \mathrm{EIP} /$ ha in 2001 to $370 \mathrm{EIP} /$ ha in 2020 for all crops combined (Figure 2). This is a reduction of more than $75 \%$ [56]. The most significant decrease occurred in the first four years, after which the EIP remained relatively stable and low ( $<500 \mathrm{EIP})$. This is a good result, considering the large increase in participating farmers, crop area and the number of crops with high disease and pest pressure. The number of participating farms increased from 23 to 170 in the GWPAs, with an increase in surface of 160 ha in 2001 to about 4000 in 2019 ( $85 \%$ of the total area).

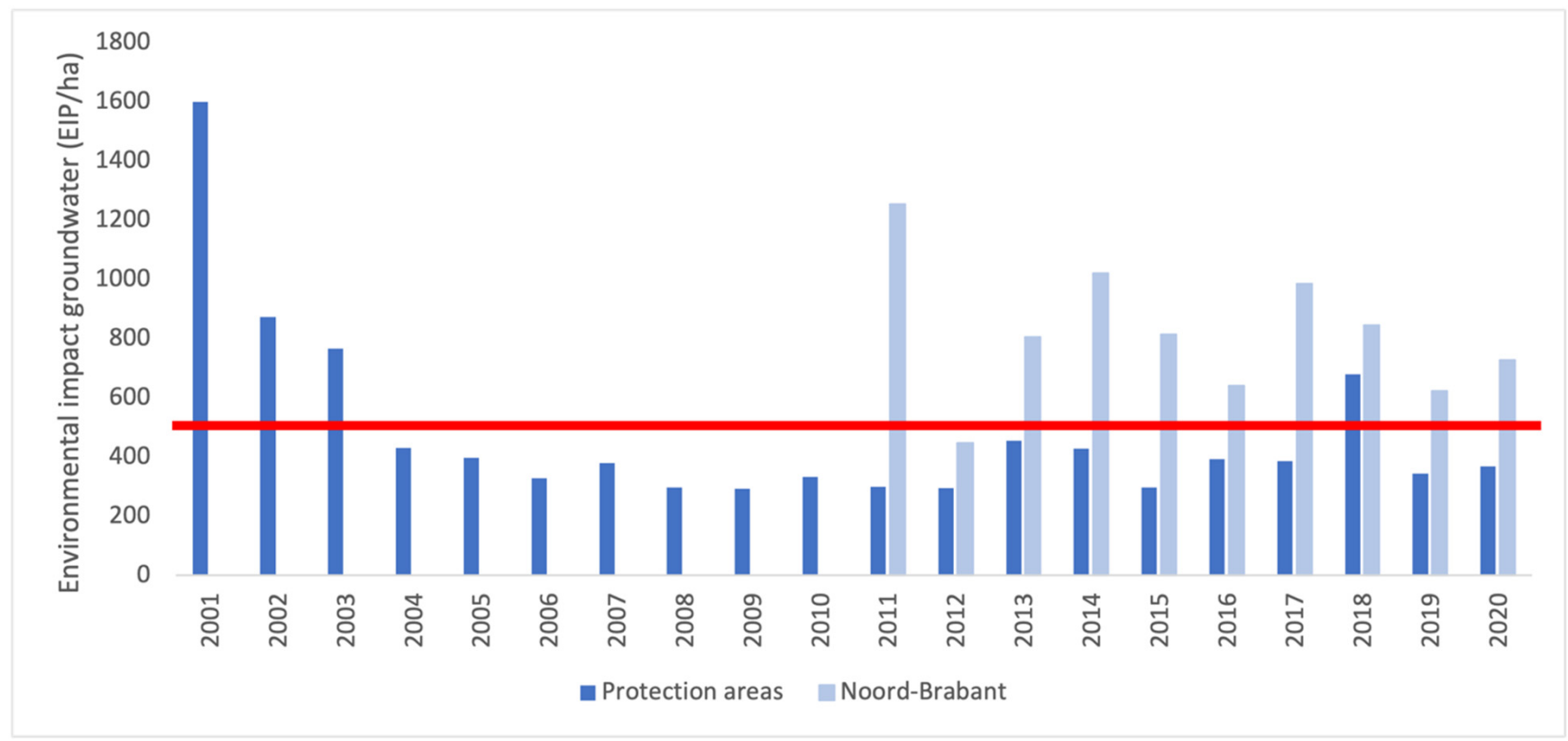

Figure 2. Environmental impact points (EIP/ha) within GWPAs and in the rest of Brabant between 2001 and 2020 for all crops. The red line indicates the target value of $500 \mathrm{EIP} / \mathrm{ha}$.

For the farmers outside of the GWPAs, the reduction in EIP was about 50\% from 2011 to 2019. This is still significant, as these farmers do not have access to individual meetings with an advisor, and their main goal is the reduction in surface water EIP, not groundwater EIP. For the whole of Brabant, farmer numbers increased from 70 to 370 and the participating area increased from an estimated 20,000 ha in 2011 to an estimated 60,000 ha in 2019.

An important note is that the reduction on a regional level depends on the crops grown. Some crops, such as grass and maize, can be grown.

For other crops, such as potato and asparagus, the reduction is difficult and is very dependent on climatic conditions. Disease and pest pressure are also high in these crops. In addition, the availability of "green" pesticides is limited, making it a challenge to reduce environmental impact to the groundwater. While improvements have been achieved over the years (Figure 3), changes in the scientific review of the leaching potential of three main pesticides have made advising the farmers in a consistent way difficult. Initially, these three pesticides were avoided by farmers due to the supposed leaching risk. Eventually, this led to a decrease in environmental impact. After a review of the leaching risk, the trend in environmental impact in potato farming has partly reversed between 2011 and 
2019. Still, for all crops, the environmental impact to groundwater is lower in the GWPAs compared to the rest of Brabant.

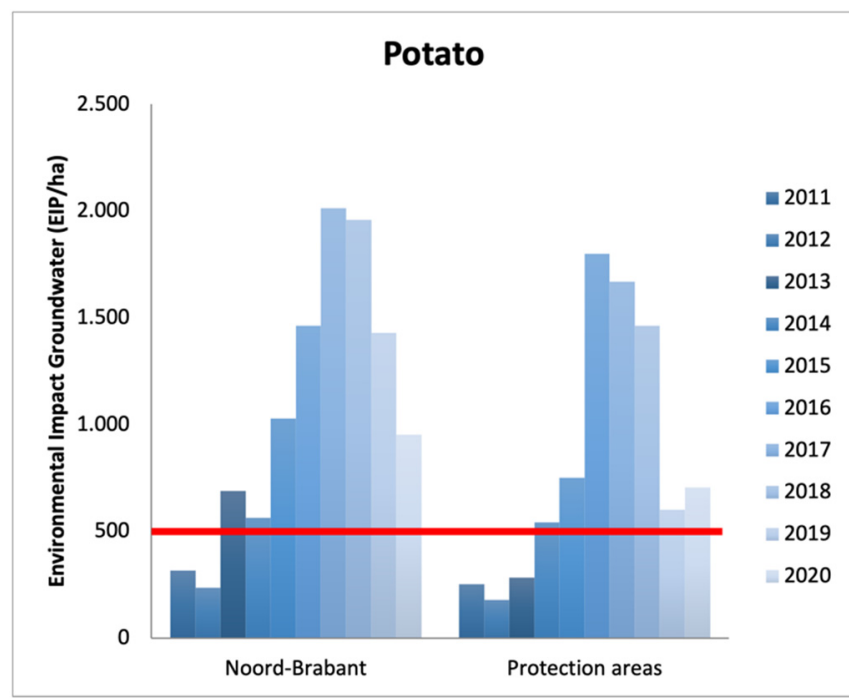

(a)

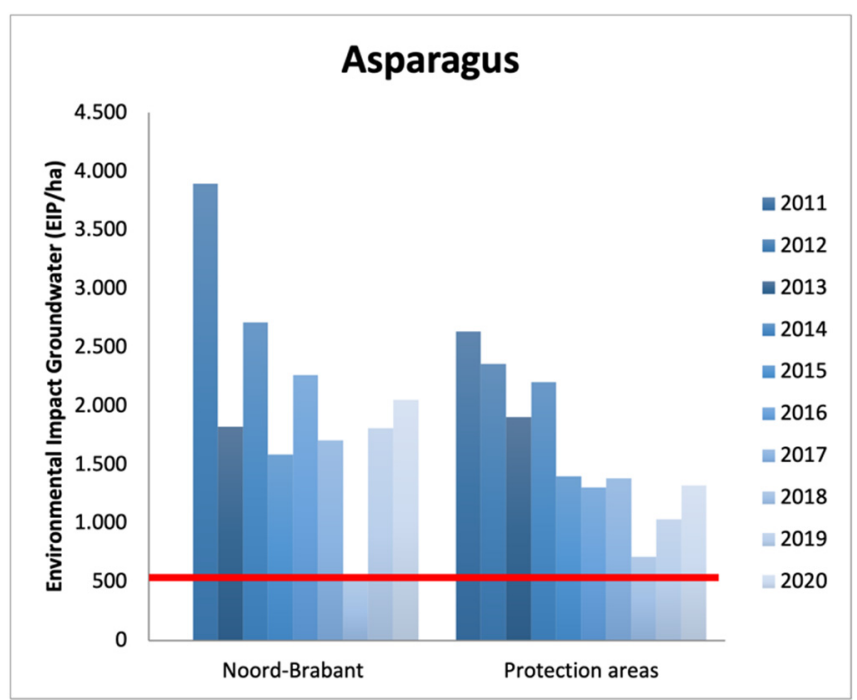

(b)

Figure 3. Environmental impact points (EIP/ha) within GWPAs and in the rest of Brabant between 2011 and 2020 for (a) potato and (b) asparagus. The red line indicates the target value of $500 \mathrm{EIP} / \mathrm{ha}$.

While it is relatively difficult for potato or asparagus growers to reduce their environmental impact to below the target value of $500 \mathrm{EIP} / \mathrm{ha}$ as a group, there are signs that it is not impossible to reach the target. When analyzed individually, the $25 \%$ of growers with the lowest environmental impact show that they can collectively stay below the $500 \mathrm{EIP} / \mathrm{ha}$ (Figure 4). Most of the growers in the $<500 \mathrm{EIP} /$ ha group are from the GWPAs, showing that the voluntary measures can work with regular advice, even for the most challenging of crops.

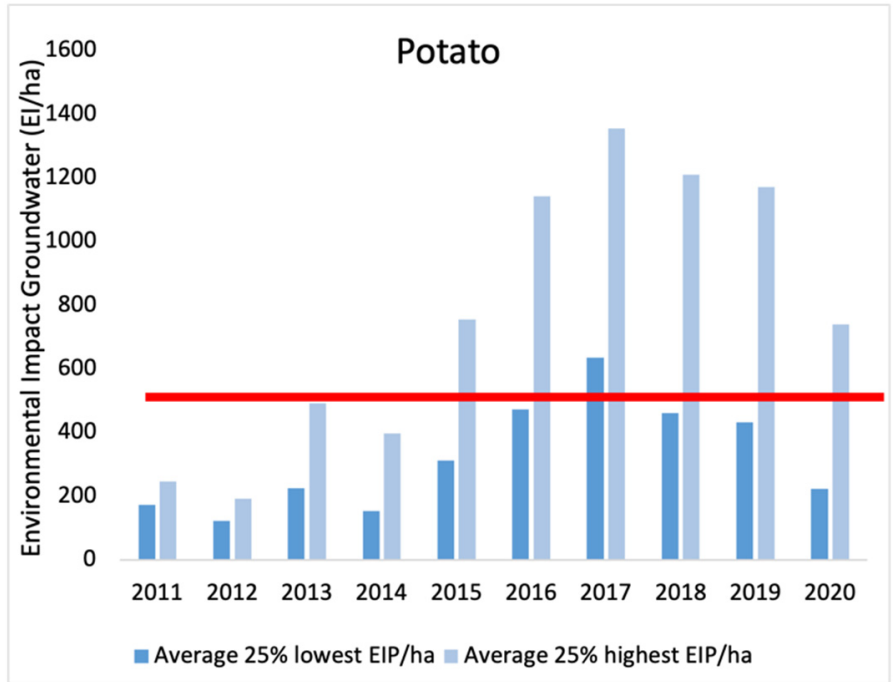

(a)

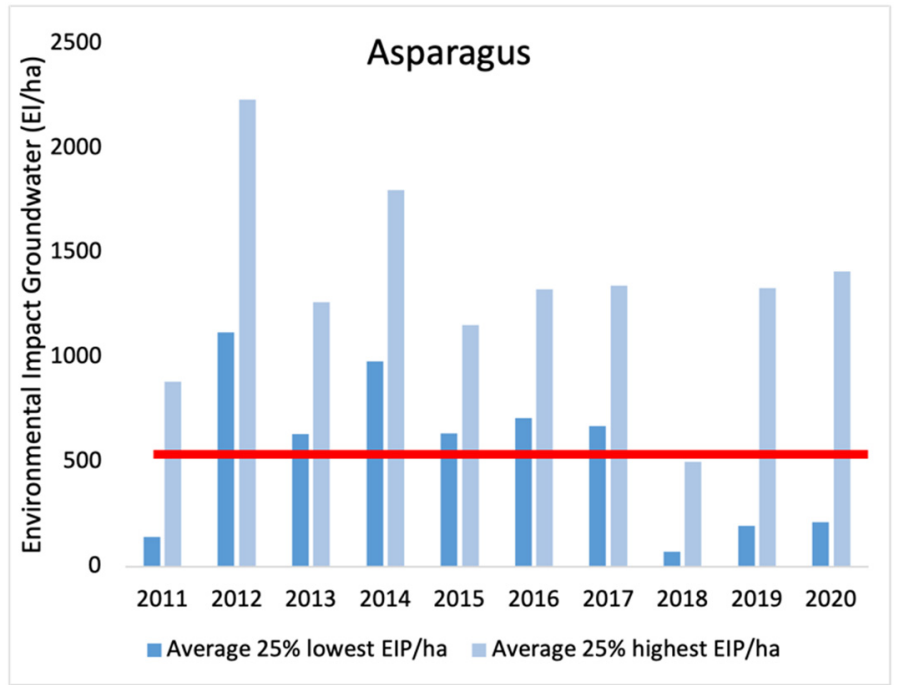

(b)

Figure 4. Environmental impact points (EIP/ha) for the 25\% highest scoring farmers and 25\% lowest scoring farmers for (a) potato and (b) asparagus. Figures include farmers in and out of the protection areas. The red line indicates the target value of $500 \mathrm{EIP} / \mathrm{ha}$.

An important difference between GWPAs and the rest of Brabant is the possibility of receiving individual advice from independent advisors. Farmers growing crops such as 
asparagus and potato receive free annual visits from an expert. For other crops, a decision is based on the results of the previous year. The growers with the highest impact also receive an individual visit. During these visits the crop protection bottlenecks of the previous year are discussed, as well as solutions for the coming season. Individual advice increases the trust farmers have in measures proposed (such as choosing a less impactful pesticide or delaying the moment of application), although it is expensive compared to group advice.

A second distinction is that farmers in GWPAs do not have access to the same pesticides as farmers outside the protection areas. A number of pesticides with high leaching potential are banned in Dutch GWPAs, resulting in a smaller package of active substances. This makes full control of all pests, weeds and/or diseases in these areas a challenge. Research on limitations and solutions for crop protection in the areas is currently ongoing.

\subsubsection{Economic Impact of Measures}

While the cost of some new measures can be high, the objective of the project is to reduce costs in the long term. Often, the costs of investment are reduced over time by savings in pesticides, while yields stay the same. An example of this is an emission reducing technique, such as the Wingssprayer or air support. These techniques require a lower dose of pesticides, with reductions up to $30 \%$. They also allow the farmer to spray under more varying weather conditions and give better coverage than conventional spraying methods. This way, the farmers often have lower labor and pesticide costs while maintaining crop quality. Other examples include reducing pesticide use by decision support tools and mechanical weeding systems.

Some measures have no economic benefits. Examples of this include techniques to reduce spot emissions from washing and filling spray equipment, such as biofilters and phytobacs. These measures have no direct economic benefit for the farmer, while there are costs to setting them up. In these situations, subsidies have been used as an incentive. There have also been campaigns where the water in the farm well was analyzed to raise awareness. While this is effective with some farmers, not all are willing to spend money without some form of compensation.

\section{Discussion}

\subsection{Engagement Process}

Within the Overijssel and Brabant projects there is broad consensus that the engagement process enlarges the knowledge base of the processes and increases the legitimacy of the outcomes and the experienced ownership influence over them. The process also fits in the paradigm shift described by [11] by providing more power to local and regional authorities, moving to a new management level at a regional scale. The mutual gains approach, together with a genuine focus on improving the efficient use of nutrients and pesticides-and therefore improving the economics of the farm-helped to build trust and reduced the impact of agricultural pollutions. This is valuable for understanding the other viewpoints, creating a shared understanding of the issue to be solved and forming a common foundation from which to solve issues. Farmers value not only this platform, but also the equality of stakeholders in this platform. They feel free to discuss issues with the authorities (province) and water company from an equal standing.

However, as the time-bound objectives of the WFD remain out of reach, all stakeholders realize what has been mentioned by Wiering and colleagues [57]: that advancing scientific knowledge alone cannot resolve the problems of controversy and delay in advancing policies to address diffuse agricultural sources. The MAP analysis carried out as part of the FAIRWAY project [43] and the annual meetings of Farmers for Drinking water showed that the arena of issues and conflicts between drinking water sources and agriculture is complex and results in pressure on the trust when groundwater standards remain out of reach despite common effort and achievements, as is the situation in the Overijssel case. In addition, the front runners of the farmers experience the limitations of the approach when 
they realize that additional effort in improving the nutrient efficiency will not result in a proportional improvement of the economic result.

Overall, the farmers consider the engagement meaningful and the project successful, even realizing that the groundwater quality objectives are still out of reach. However, despite the awareness of the farmers and shared notion on the objectives of the project, they keep asking for financial incentives as compensation for their efforts. In addition, as the groundwater objectives remain out of sight and the deadline of 2025 is approaching, the effort of the farmers and the groundwater objectives are becoming two separate entities: "We (the farmers) are putting a lot more effort in our management to meet your groundwater quality objectives. What is in it for us?".

For pesticides the situation is different. Due to the possibility of shifting to less harmful products or mechanical solutions, the groundwater quality objectives $(<500 \mathrm{EIP})$ can be met at the scale of GWPA. However, the skills and commitment of the farmers to meet these objectives require continuous effort in engaging and supporting farmers to maintain their focus on groundwater quality.

The effort to keep pesticide emissions below the threshold takes place in a competitive arena with companies that provide free advice in exchange for being the preferred pesticide seller. Although they are generally good advisors, including measures to avoid point source emissions, their primary focus is to protect the crop and yield, more so than the groundwater. These companies often have long-term relations with the farmers and regularly check on the progress regarding pest and weed control. Additionally, new pests and diseases develop, fueling the need for continuous research and advice. Without regular and personal advice from an independent advising party with a focus on groundwater-friendly techniques or use of pesticides, farmers are not updated on new low-environmental-impact pesticides or techniques and gradually lose their focus.

\subsection{Effectiveness of Farm Scale Measures}

The effectiveness of the project Farmers for Drinking Water (Overijssel) expressed as reduction in nutrient losses is significant (approx. 40\%). More specifically, $154 \mathrm{kgN} / \mathrm{ha}$ minus $89 \mathrm{kgN} /$ ha over the period between 2012 and 2017-and—except for 2018-more or less stable thereafter. This reduction is far greater than the $4.3 \%$ nutrient loss, as reported by a comparable initiative in the UK-Catchment Sensitive Farming (CSF) [58]. The reduction in the N-surpluses was not reflected in an improved groundwater quality. In that respect, the choice of a nitrate-monitoring network at the GWPA level, rather than the at farm level, increased the problem of indirect feedback of agricultural management by groundwater quality data. Contrary to CSF, the reduction in the N-surpluses flattens after 3-5 years, while CSF reports a clear relationship between the amount of time CSF has been targeted in a specific area and the resulting pollutant reduction, due to one-on-one advice and capital grants [58].

Despite the fact that Farmers for Drinking Water is unable to use capital grants, the effectiveness is at least similar to the CSF. This might be due to the focus on the BE-gain by implementing nutrient efficient measures combined with lecturing the economics of these measures in (peer) group meetings. On the other hand, the implementation of new measures and intrinsic improvement by analysis of the ANCA by individual farmers was hampered when implementation could not be motivated economically. The interest of 'clean groundwater', as such, is not economically strong enough and requires continuous investment-at least as advice. Advice can also be promoted effectively in a practical farm setting where farmers learn from each other's experiences and visualize benefits in a tangible way [59]. Such peer group interactions allow confidence and skills to be developed and help establish groundwater-friendly farming as a good farming 'norm'. A mix of one-to-one and group events, as practiced by Farmers for Drinking Water, can therefore be seen as optimal for effective delivery.

The effectiveness of the Clean Water project (Brabant), expressed as reduction in EIP, is significant. The main features have been a $75 \%$ reduction since 2001 and meeting the ob- 
jective of $<500$ EIP in GWPAs since 2004. As the project entails over $85 \%$ of the agricultural land in the GWPAs, the reduction is likely to have an effect on future groundwater quality. An important basis for this effectiveness is the fact that these results can be obtained without BE-loss for individual farmers, and they boast a high participation rate at the GWPA level. This participation enables the leveling of the impact of crops that have a high need for pesticides (e.g., potatoes and asparagus) with crops that have a low need, such as grass and maize. However, a visible trend shows farmers moving from low-impact crops, such as maize and grass, towards high-impact crops, such as potato, asparagus or sugar beet. This trend puts pressure on groundwater quality in the long term. Furthermore, new diseases put pressure on the balanced use of pesticides and techniques because it takes some time to find the new balance in applying the right amount of pesticide at the right moment in combination with mechanical measures (e.g., drift reduction and mechanical weeding).

The results of the Clean Water project are under pressure by free advice from pesticideselling companies, climate change and changes in cropping system. Free advice given by companies linked to pesticide dealers is often given with the best interest of the farmer in mind, but it is more conservative than advice given by independent advisors, especially when the advice is financed by a project with emission reduction as its goal. Farmers have long-term relationships with their advisor and receive regular communications about the latest information on pests and diseases found in their area (with related pesticide advice). However, this information generally does not include advice regarding reducing or delaying pesticide use, or alternative pesticides with a lower impact on the groundwater. Advice is given purely to keep the crops clean of pests, diseases and herbs.

Climate change increases the appearances of new pests and diseases. With pests becoming more specific, new pesticides need to be developed for these new issues. However, these pesticides are not always low impact, as admission criteria do not always block high-impact pesticides. Additionally, extreme weather conditions such as heavy rain or drought cause stress in the crops, which in turn increases their sensitivity to pests and diseases.

Change in cropping systems may affect the use of pesticides. Crops such as potato and asparagus give good return on investment and as such, are important to the financial stability of the farmers. However, as high-impact crops, they are a risk to groundwater quality. The total area of these crops in Brabant has slowly increased over the years. For instance, potato crops grew from 15,000 to 22,500 ha between 2005 and 2019, and asparagus crops grew from 850 to 1300 ha between 2005 and 2019 [60].

\subsection{Effectiveness of the Voluntary-Based Governance Approach}

Although it is difficult to relate governance approaches to water quality improvements, Wuijts et al. [61] provided a framework to assess the effectiveness of water quality governance from the ecological, legal and social-economic perspectives. From their study, it appeared that potentially conflicting characteristics are (i) the difficulty of setting objectives (involving many unknowns) and adequate measures from the ecological perspective, (ii) the limited adaptive capacity of the legal framework once set in place and (iii) the focus on decision-making processes rather than water quality improvement from the socialeconomic perspective. In the case of nitrate and pesticides, objectives are set by the WFD. However, the limited adaptive capacity of the governance and legal framework and the balanced trade-off with other interests, such as maintaining the level playing field for agriculture, particularly hamper realization of the groundwater quality objectives.

The adaptive capacity of the legal and governance framework are limiting factors for long-term sustainability of the engagement process. Continuous investments in groundwater-friendly approaches and measures by all partners in the water chain are necessary to form a counterbalance within this arena. The forementioned initiative CSF does have capital grants, and they concluded that 'Cost is the most significant barrier to implementation of measures, but capital grants (initially available through CSF and now through Countryside Stewardship) are a strong enabler and driver of action' [62]. 
The economic analysis revealed diminishing economic returns on the effort of farmers, and it was concluded that additional measures could not be motivated from an economic perspective alone. However, even though farmers are asking for capital grants in almost every meeting, the current framework will not change in that direction in the near future. This was illustrated during a national webinar about the future of agriculture organized by the ministry of Agriculture, Nature and Food Quality on 13 October 2020, which was attended by over 400 policy makers, experts, agricultural advisors, agricultural lobby organizations, water companies, water boards, provinces and farmers. When asked 'how to improve (ground)water quality', $29 \%$ voted for the need for more (ground)water quality data, $37 \%$ voted for the need for more knowledge about effective measures and only $11 \%$ voted for the need for financial arrangements or payment schemes. Note that these percentages are estimates because not all participants answered all questions.

The result of the balanced trade-off of WFD objectives with interests such as agricultural interests is illustrated by the Dutch parliament, which decided that WFD implementation should not lead to additional costs for the agricultural sector [36]. This implies that the WFD objectives must be met using voluntary measures only. Consequently, WFD objectives may not be reached, as the voluntary approach is organized as a collaborative process with no clear end point rather than a mandatory process in which additional rules, regulations and enforcement guarantee these objectives are met. The downside is that there is no political support for any payment scheme or subsidies if concentrations still do not meet the standards, either for planning instruments such as rezoning, or for land retirement. This observation is in line with the increasing evidence that the WFD has difficulties with directly intervening in agricultural policies, especially when source-based measures are involved. These obviously interfere more with the 'business model' of farmers, and effectbased measures provide more flexibility and options for differentiation [58]. On the other hand, Wuijts et al. [61] state that governance approaches such as voluntary-based measures, with the involvement of multiple actors at multiple levels, are often more effective in dealing with complex water issues than conventional legal frameworks with centrally organized top-down mechanisms [62-64]. In this context, governance is defined as a process of interaction between public and/or private actors, ultimately aiming to realize collective goals [65]. The engagement processes of both Overijssel and Brabant reflect the effectiveness of voluntary-based measures in terms of the involvement of multiple actors at multiple levels and improvement of agricultural management, but the constraining factors-especially the lack of source-based measures—inhibit the realization of the WFD objectives in the Overijssel case, while they are met in the Brabant case.

The concern of individual farmers of the Farmers for Drinking Water project about 'what will be next if we are not able to meet the groundwater quality standards' increased during the scope of the project, especially when they realized that protection of the drinking water abstraction is not just an objective of the regional authority or drinking water company, but that meeting these standards in the entire recharge area had also been confirmed by a national agreement on nitrate leaching in specific vulnerable GWPAs [53], with the agricultural lobby organization as a co-subscriber. This concern is realistic, given the fact that farmers participating in the project do not meet the nitrate objective, and that the current participation rate is still only $53 \%$ of the agricultural area in the GWPAs as of 2021. The engagement process, as a well-functioning platform of collaboration, may serve as a vehicle for the required transition of agriculture within the vulnerable GWPAs, in which additional measures will have to be selected. The objective of this transition will be 'economically feasible agriculture meeting environmental standards even in very vulnerable GWPAs'.

The situation for the Clean Water for Brabant project is different from the situation of Farmers for Drinking Water Overijssel for two reasons. First, the EIP objective is not a formal standard following from an EU directive or national agreement and does not have a strict deadline. Second, Clean Water for Brabant shows that the drinking water limit of $<500 \mathrm{EIP}$ (or $0.5 \mu \mathrm{g} / \mathrm{ha}$ for all pesticides) can be met at the level of the GWPAs without BE 
losses for the farmers. The fact that an enforceable objective connected with a deadline is missing, contributes to a more equal power balance in which the emphasis lies on characteristics for meaningful engagement such as building trust, exchanging knowledge and sharing dilemmas, rather than a growing uncertainty regarding the next step of the national and regional authorities and drinking water company to meet the objectives in time. The fact that the objective of $<500$ EIP can be met without BE losses opens the opportunity for farmers to profile themselves-and not just as a groundwater-friendly farmer. Several farmers profile their farm as sustainable, fit for the future and producing healthy products for their customers.

However, despite these examples, keeping farmers focused on groundwater-friendly techniques and pesticide use in a competitive arena requires continuous engagement efforts when participation and measures can only be based on voluntariness. A reduction in participation or measures may well lead to a discussion on whether obligatory measures will be needed soon.

\section{Conclusions}

The governance approach process based on voluntariness creates a platform for meaningful engagement and helps to build trust and equity, facilitating the exchange of ideas, knowledge and experience. The approach applied in the case studies in Overijssel and Brabant improves agricultural management, adds to the economics of the farm, reduces the agricultural impact on groundwater quality through the reduction in $\mathrm{N}$-surpluses and environmental impact points and creates a well-functioning collaboration.

Despite the improvement of agricultural management of the participating farmers in the Overijssel case, the nitrate objectives are not met at the level of the GWPAs. The voluntariness of the approach plays an important role. Due to this approach, the participation rate relies on the farmers' expectations regarding the costs and profits of the process, negatively affecting the participation rate of farmers in the GWPAs and therefore also affecting the potential effectiveness of the approach. Voluntariness also hampers the implementation of additional measures needed to meet the objectives of nitrate in the groundwater which do not contribute to the economics of the farm. In addition, diminishing economic returns prevent the further improvement of efficient use of nutrients. The fact that enforceable groundwater objectives with a strict deadline remain out of reach puts pressure on the engagement process and trust between stakeholders.

Although an enforceable objective and strict deadline is missing for EIP in the Brabant case, the objective of $<500 \mathrm{EIP} /$ ha is met at the level of GWPAs using voluntary measures and techniques only. An important driver for this effectiveness is the fact that these results can be obtained without $\mathrm{BE}$ losses for individual farmers and a high participation rate at the level of the GWPAs. The trend of farmers moving from low-impact crops such as maize and grass towards high-impact crops such as potato, asparagus or sugar beet, puts pressure on the effectiveness of the approach and engagement process, because this trend moves soil use away from the objectives. Keeping farmers focused on groundwater-friendly techniques and pesticide use in a competitive arena therefore requires continuous engagement efforts for as long as participation and measures can only be based on voluntariness.

Author Contributions: Conceptualization, C.v.d.B.; methodology, C.v.d.B. and K.V.; formal analysis, C.v.d.B., M.H. and K.V.; data curation, C.v.d.B., M.H. and K.V.; writing-original draft preparation, C.v.d.B., M.H. and K.V., writing—review and editing, C.v.d.B., M.H., K.V., A.d.V. and P.L.; Project Administration, C.v.d.B. All authors have read and agreed to the published version of the manuscript.

Funding: This project received funding from the European Union's Horizon 2020 research and innovation program under grant agreement No. 727984.

Institutional Review Board Statement: Not applicable.

Informed Consent Statement: Not applicable.

Data Availability Statement: Data are presented in the text. 
Acknowledgments: Thanks are due to the participants of the engagement processes (farmers, agricultural advisors, water company, water board, province) for their effort and financial support of Farmers for Drinking Water Overijssel and Clean Water for Brabant. In addition, the authors would like to thank the anonymous reviewers for their valuable comments on an earlier version of this article.

Conflicts of Interest: The authors declare no conflict of interest.

\section{References}

1. Dobson, A.P.; en Bradshaw, A.D.; Baker, A.J.M. Hopes for the future: Restoration ecology and conservation biology. Science 1997, 277, 515-522. [CrossRef]

2. Aarts, H.F.M.; Biewinga, E.E.; Van Keulen, H.H. Dairy farming systems based on efficient nutrient management. Neth. J. Agric. Sci. 1992, 40, 285-299. [CrossRef]

3. Verloop, J. Limits of Effective Nutrient Management in Dairy Farming: Analyses of Experimental Farm De Marke. Ph.D. Thesis, Wageningen University, Wageningen, NL, USA, 2013.

4. Dufour, F.C. Groundwater in the Netherlands-Facts and figures. In Netherlands Institute of Applied Geoscience TNO; National Geological Survey: Delft, The Netherlands; Utrecht, The Netherlands, 2000; ISBN 90-6743-654-2.

5. Van den Brink, C.; Wuijts, S. Towards an effective protection of groundwater resources: Putting policy into practice with the Drinking Water Protection File. Water Policy. Water Policy 2016, 18, 635-653. [CrossRef]

6. EC. Green Paper on Perspectives for the Common Agricultural Policy; Communication of the Commission to the Council and Parliament, COM(85) 333; European Communities: Brussels, Belgium, 1985. Available online: Aei.pitt.edu/931/1/perspectives_ for_cap_gp_COM_85_333.pdf (accessed on 8 July 2021).

7. BGDM (Besluit Gebruik Dierlijke Meststoffen). National Law for A Stepwise Reduction of the Amount of Manure to Be Applied in Agriculture; Ministry of Economic Affairs and Climate Policy: The Hague, The Netherlands, 1997. (In Dutch). Available online: https: / / wetten.overheid.nl/BWBR0009066/2021-02-20 (accessed on 8 July 2021).

8. Cortner, H.J.; Moote, M.A. Setting the political agenda: Paradigmatic shifts in land and water policy. In Environmental Policy and Biodiversity; Grumbine, R.E., Ed.; Island: Washington, DC, USA, 1994; pp. 365-377.

9. Withanachchi, S.S. The study of Transboundary Groundwater Governance in the notion of Governmentality: In the case of Guaraní Aquifer. AQUA Mundi 2012, 1, 9-14.

10. EC. Directive 2000/60/EC of the European Parliament and of the Council of 23 October 2000 Establishing a Framework for Community Action in the Field of Water Policy; OJ L327; European Commission: Brussels, Belgium, 2000.

11. Withanachchi, S.S.; Ghambashidze, G.; Kunchulia, I.; Urushadze, T.; Ploeger, A. A paradigm shift in water quality governance in a transitional context: A critical study about the empowerment of local governance in Georgia. Water 2018, 10, 98. [CrossRef]

12. Driessen, P.P.J.; Glasbergen, P. New Directions in Environmental Politics. Concluding Remarks. In Greening Society. The Paradigm Shift in Dutch Environmental Politics; Driessen, P.P.J., Glasbergen, P., Eds.; Kluwer Academic Publishers: Dordrecht, The Netherlands, 2002; pp. 245-262.

13. Lach, D.; Rayner, S.; Ingram, H. Taming the waters: Strategies to domesticate the wicked problems of water resource man-agement. Int. J. Water 2005, 3, 1-17. [CrossRef]

14. Renn, O. Risk Governance: Coping with Uncertainty in a Complex World; Earthscan: London, UK, 2008.

15. De Roo, G. Planning se per, Planning per Saldo: Conflicts, Complexity and Decision-Making in Environmental Planning. Ph.D. Thesis, Groningen University, SDU Uitgevers, Den Haag, The Netherlands, 1999; p. 430. (In Dutch)

16. Driessen, P.P.J.; Glasbergen, P. Environment, Society and Policy; Elsevier: The Hague, The Netherlands, 2000; p. 474. (In Dutch)

17. Niekerk, F. The Impact Reported. The of Impact Assessments for the Planning of Traffic Infrastructure. Ph.D. Thesis, Groningen University, Groningen, The Netherlands, 2000; p. 392. (In Dutch)

18. Simpson, H.G.; de Loë, R.C. Challenges and opportunities from a paradigm shift in groundwater governance. Hydrogeol. J. 2020, 28, 467-476. [CrossRef]

19. Reed, M.S. Stakeholder participation for environmental management: A literature review. Biol. Conserv. 2008, 141, $2417-2431$. [CrossRef]

20. Lamers, M.; Ottow, B.; Francois, G.; von Korff, Y. Beyond Dry Feet? Experiences from a Participatory Water-Management Planning Case in The Netherlands. Ecol. Soc. 2010, 15, 14. [CrossRef]

21. Akhmouch, A.; Clavreul, D. Stakeholder Engagement for Inclusive Water Governance: "Practicing What We Preach" with the OECD Water Governance Initiative. Water 2016, 8, 204. [CrossRef]

22. Ten Heggeler, M.; van den Brink, C.; van Essen, J. Gebiedsdossiers voor kwetsbare drinkwaterwinningen in Overijssel. $\mathrm{H}_{2} \mathrm{O}$ 2010, 7, 4-6. (In Dutch). Available online: https:/ / edepot.wur.nl/340202 (accessed on 8 July 2021).

23. Van den Brink, C.; Heggeler, M.T. Eerste maatregelprogramma kwetsbare drinkwaterwinningen Overijssel 2010-2012. In First Action Plan for the Vulnerable Groundwater Abstraction Sites of the Province of Overijssel; Province of Overijssel: Zwolle, The Netherlands, 2010. (In Dutch)

24. Van den Brink, C.; ten Heggeler, M.; van Essen, J. Uitvoeringsprogramma gebiedsdossiers in Overijssel. $\mathrm{H}_{2} \mathrm{O}$ 2011, 14/15, 22-23. (In Dutch). Available online: https:/ / edepot.wur.nl/339574 (accessed on 8 July 2021). 
25. Gooijer, Y.M.; Leendertse, P.C. Schoon Water voor Brabant. In Deel A Managementsamenvatting; CLM Rapport 902; CLM: Culemborg, The Netherlands, 2016.

26. Hoogendoorn, M.; Veenenbos, M.; Rougoor, C.; van Vliet, J.; Folkersma, R.; Leendertse, P.C.; Krassenberg, N. Schoon Water Voor Brabant Rapportage over 2019; CLM Rapport 1033; CLM: Culemborg, The Netherlands, 2020.

27. Lang, D.J.; Wiek, A.; Bergmann, M.; Stauffacher, M.; Martens, P.; Moll, P.; Swilling, M.; Thomas, C.J. Transdisciplinary research in sustainability science: Practice, principles, and challenges. Sustain. Sci. 2012, 7, 25-43. [CrossRef]

28. Closas, A.; Villholth, K.G. Groundwater governance: Addressing core concepts and challenges. Wiley Interdiscip. Rev. Water 2020, 7, e1392. [CrossRef]

29. Smith, L.; Inman, A.; Lai, X.; Zhang, H.; Fanqiao, M.; Jianbin, Z.; Burke, S.; Rahn, C.; Siciliano, G.; Haygarth, P.; et al. Mitigation of diffuse water pollution from agriculture in England and China, and the scope for policy transfer. Land Use Policy 2017, 61, 208-219. [CrossRef]

30. OECD. Water Quality and Agriculture: Meeting the Policy Challenge. OECD Studies on Water; OECD Publishing: Paris, France, 2012.

31. Carter, N. The Politics of the Environment; Cambridge University Press: Cambridge, UK, 2007.

32. Graversgaard, M.; Hedelin, B.; Smith, L.; Gertz, F.; Højberg, A.L.; Langford, J.; Martinez, G.; Mostert, E.; Ptak, E.; Peterson, H.; et al. Opportunities and Barriers for Water Co-Governance-A Critical Analysis of Seven Cases of Diffuse Water Pollution from Agriculture in Europe, Australia and North America. Sustainability 2018, 10, 1634. [CrossRef]

33. Van Gaalen, F.; Osté, L.; van Boekel, E. Nationale Analyse Waterkwaliteit. In National Analysis Water Quality; PBL Planbureau voor de Leefomgeving: Den Haag, The Netherlands, 2020. (In Dutch)

34. Verhagen, F.T.; Holsteijn, A.; Schipper, M. Feitenrapportage Brede Screening Bestrijdingsmiddelen en Opkomende Stoffen Maasstroomgebied 2016; RHDHV Report BF1729; RHDHV: Amersfoort, The Netherlands, 2018.

35. Parliamentary Papers, 27625 Water Policy, Amendment Van der Vlies No. 92; Tweede Kamer der Staten-Generaal: The Hague, The Netherlands, 2007. Available online: https:/ / zoek.officielebekendmakingen.nl/kst-27625-92.html (accessed on 8 July 2021).

36. WUR. Farm Systems that Produce Good Water Quality for Drinking Water Supplies FAirWAY. H2020-CP-STAGE2-RIA-CSA, Proposal Number: 727984-2. 2016. Available online: https:/ / cordis.europa.eu/project/id/727984 (accessed on 8 July 2021).

37. Aarts, H.F.M.; Habekotte, B.; van Keulen, H. Nitrogen (N) management in the 'De Marke' dairy farming system. Nutr. Cycl. Agroecosyst. 2000, 56, 231-240. [CrossRef]

38. Schröder, J.J.; Aarts, H.F.M.; van Middelkoop, J.C.; Schils, R.L.M.; Velthof, G.L.; Fraters, B.; Willemse, W.J. Permissible manure and fertilizer use in dairy farming systems on sandy soils in The Netherlands to comply with the Nitrates Directive target. Eur. J. Agron. 2007, 27, 102-114. [CrossRef]

39. Reus, J.A.W.A.; Leendertse, P.C. The environmental yardstick for pesticides: A practical indicator used in the Netherlands. Crop Prot. 2000, 19, 637-641. [CrossRef]

40. Leendertse, P.C.; Hoftijser, E.; Lageschaar, L. Milieumeetlat voor bestrijdingsmiddelen in de open teelt-Achtergrondnotitie. In Environmental Yardstick for Pesticide Use in Open Cropping Systems; CLM Rapport 1007; CLM: Culemborg, The Netherlands, 2019. (In Dutch)

41. Van den Brink, C.; Zaadnoordijk, W.J.; van der Grift, B.; de Ruiter, P.C.; Griffioen, J. Using a groundwater quality negotiation support system to change land-use management near a drinking-water abstraction in the Netherlands. J. Hydrol. 2008, 350, 339-356. [CrossRef]

42. Fisher, R.; Ury, W.; Patton, B. Getting to Yes: Negotiating an Agreement without Getting in; Houghton Mifflin: Boston, MA, USA, 1991; 200p.

43. Sundnes, F.; van den Brink, C.; Graversgaard, M. Advancing MAPs as Vehicles for Resolving Issues on Drinking Water Pollution from Agriculture. Report was Written in the Context of the FAIRWAY Project. Available online: www.fairway-project.eu (accessed on 14 September 2021).

44. Fraters, B. Uitspoelingsgevoeligheid (UG) voor berekening uitspoeling N-Overschot in 34 Grondwaterbeschermingsgebieden. In Empirical Relation to Calculate Nitrate Leaching as Function of the Vulnerability of the Soil in 34 Vulnerable Groundwater Protection Areas; RIVM Rapport 680716002/2007; RIVM: Bilthoven, The Netherlands, 2007. (In Dutch). Available online: https://edepot.wur.nl/ 19104 (accessed on 8 July 2021).

45. Roelsma, J.; Brus, D.; Heidema, N.; van den Brink, C. Nitraatmonitoring kwetsbare drinkwaterwinningen in Overijssel. In Meetrondes 2011 en 2012 Nitrate Monitoring in Vulnerable Catchments Areas in the Province of Overijssel: 2011 and 2012; RoyalHaskoningDHV report 9X0788; RHDHV: Groningen, The Netherlands, 2013. (In Dutch)

46. Fraters, D.; Boumans, L.J.; van Drecht, G.; de Haan, T.; de Hoop, W.D. Nitrogen monitoring in groundwater in the sandy regions of the Netherlands. Environ. Pollut. 1998, 102, 479-485. [CrossRef]

47. Fraters, B.; Hooijboer, A.E.J.; Vrijhoef, A.; Claessens, J.; Kotte, M.C.; Rijs, G.B.J.; Denneman, A.I.M.; van Bruggen, C.; Daatselaar, C.H.G.; Begeman, H.A.L.; et al. Agricultural Practice and Water Quality in the Netherlands: Status (2012-2014) and Trend (1992-2014) Monitoring Results for Nitrates Directive Reporting RIVM Report 2016-0019; RIVM: Bilthoven, The Netherlands, 2016.

48. De Goffau, A.; Van Leeuwen, T.C.; Van den Ham, A.; Doornewaard, G.J.; Fraters, B. Minerals Policy Monitoring Programme Report 2007-2010; Methods and Procedures; National Institute for Public Health and the Environment: Bilthoven, The Netherlands, 2012; RIVM Report 680717018. Available online: http:/ / www.rivm.nl/bibliotheek/rapporten/680717018.pdf (accessed on 14 September 2021). 
49. Fraters, D.; Boom, L.G.J.F.; Boumans, M.L.J.; de Weerd, H.; Wolters, M. Extraction of soil solution by drainage centrifu-gationeffects of centrifugal force and time of centrifugation on soil moisture recovery and solute concentration in soil moisture of loess subsoils. Environ. Monit. Assess. 2017, 189, 83. [CrossRef]

50. Duijvenbooden, W.; Gast, L.F.L.; Taat, J. Landelijk Meetnet Grondwaterkwaliteit: Eindrapport van de inrichtingsfase. In National Groundwater Monitoring Network. Final Report of the Establishment of the Network; RIVM Rapport 840382001; RIVM: Bilthoven, The Netherlands, 1985. (In Dutch)

51. Flyvbjerg, B. Five misunderstandings about case-study research. Qual. Inq. 2006, 12, 219-245. [CrossRef]

52. Punch, K. Introduction to Social Research: Quantitative and Qualitative Approaches, 3rd ed.; Sage: London, UK, 2014.

53. IPO; LNV; IandW; Vewin; LTO. Bestuursovereenkomst "Aanvullende aanpak nitraatuitspoeling uit agrarische bed-rijfsvoering in specifieke grondwaterbeschermingsgebieden". In National Agreement 'Additional Approach to Reducing Nitrate Leaching from Agricultural Management in Specific Groundwater Protection Areas'; Tweede Kamer der Staten-Generaal: The Hague, The Netherlands, 2017. (In Dutch). Available online: https://www.tweedekamer.nl/kamerstukken/detail?id=2017Z18918\&did=2017D38906 (accessed on 8 July 2021).

54. Verloop, J.; van den Brink, C.; Gielen, J. Dairy Farming and Drinking Water Supply: A Pilot Study in a Vulnerable Sandy Area in Overijssel. Water 2021. submitted.

55. Leendertse, P.C.; Aasman, B. Schoon Water Win-Win Maatregelen voor Schoon Gronden Oppervlaktewater en een Goed Gewas. CLM/Delphy Booklet; CLM: Culemborg, The Netherlands, 2012.

56. Blok, A.; Folkersma, R.; Hoogendoorn, M.; Rougoor, C.; van Vliet, J.; Leendertse, P.; Krassenberg, N. Schoon Water voor Brabant Rapportage over 2020; CLM Rapport 1085; CLM: Culemborg, The Netherlands, 2021.

57. Wiering, M.; Boezeman, D.; Crabbé, A. The Water Framework Directive and agricultural diffuse pollution: Fighting a running battle? Water 2020, 12, 1447. [CrossRef]

58. Environment Agency. Catchment Sensitive Farming Evaluation Report_Water Quality, Phases 1 to 4 (2006-2018); Natural England Publication: Worcester, UK, 2019. Available online: Publications.naturalengland.org.uk/publication/4538826523672576 (accessed on 8 July 2021).

59. Fish, R.; Ioris, A.A.R.; Watson, N.M. Integrating water and agricultural management: Collaborative governance for a complex policy problem. Sci. Total Environ. 2010, 408, 5623-5630. [CrossRef]

60. CBS StatLine Open Data Portal. 2021. Available online: https://opendata.cbs.nl/statline/portal.html?_la=nl\&_catalog=CBS (accessed on 14 September 2021).

61. Wuijts, S.; Driessen, P.P.; Van Rijswick, H.F. Towards more effective water quality governance: A review of so-cial-economic, legal and ecological perspectives and their interactions. Sustainability 2018, 10, 914. [CrossRef]

62. Howarth, W. Water pollution and water quality—Shifting regulatory paradigms. In Handbook on Water Law and Policy; Howarth, W., Rieu-Clarke, A., Allen, A., Hendry, S., Eds.; Routlegde: Abingdon, UK, 2017.

63. Lee, M. Law and governance of water protection policy. In EU Environmental Governance; Scott, J., Ed.; Oxford University Press: Oxford, UK, 2009.

64. EC. Common Implementation Strategy for the Water Framework Directive (2000/60/EC); Guidance Document No. 3, Analysis of Pressures and Impacts; European Commission: Luxemburg, 2003.

65. Lange, P.; Driessen, P.P.J.; Sauer, A.; Bornemann, B.; Burger, P. Governing towards sustainability: Conceptualizing modes of governance. J. Environ. Policy Plan. 2013, 15, 403-425. [CrossRef] 